\title{
"Zawsze się trudna wydaje myśl nowa..."
}

Jakub Osiński

TEKSTY DRUGIE 2016, NR 5, S. 171-181

DOI: $10.18318 /$ td.2016.5.12

$\mathbf{U}$ czeń w Fauście Goethego, nie rozumiejąc, co o poznaniu powiada mu Mefistofeles, słyszy od kusiciela: „Zawsze się trudna wydaje myśl nowa...”."Zdaje mi się, że ta genialna w swej prostocie fraza z dramatu weimarskiego mistrza, niezwykle cenionego zresztą przez Freuda, nader celnie opisuje rozwój myśli psychoanalitycznej, który nieprzerwanie trwa już od przeszło stu dwudziestu lat. Co jednak zdaje mi się charakterystyczne, poglądy autora Die Traumdeutung i jego kontynuatorów w naszej rodzimej nauce wciąż uchodzą za trudne i nowe. Mimo to psychoanaliza od kilku dekad nieprzerwanie pociąga polskich humanistów, jest często wykorzystywanym i - jak się okazuje - efektywnym słownikiem teoretycznym dla wielu dyscyplin. Jednak myśl ta funkcjonuje u nas głównie dzięki pracom - oryginalnym i tłumaczonym - powstałym na Zachodzie, gdzie wybitnych jej przedstawicieli nie brakuje. Rodzime tradycje psychoanalityczne, jeśli w ogóle są obecne
Jakub Osiński - student filologii polskiej na Uniwersytecie Mikołaja Kopernika w Toruniu, sekretarz redakcji Interdyscyplinarnego Czasopisma Humanistycznego „ProLog."Współredaktor pięciu tomów zbiorowych. Interesuje się literaturą emigracyjną oraz autobiografistyką. Kontakt: jakubosinski@vp.pl.

1 J.W. Goethe Faust, przeł. E. Zegadłowicz, Wydawnictwo Akademia, Toruń 1994, S. 78. 
w świadomości badaczy, to na jej dalekim marginesie, a permanentne „doganianie" innych może wręcz uchodzić za charakterystyczną cechę większości tych przedsięwzięć badawczych.

Kiedy w 1998 roku jeden z numerów „Tekstów Drugich” zatytułowano: Powrót psychoanalizy ${ }^{2}$, zarówno autorów pomieszczonych tam rozpraw, jak i czytelników nie mogło nie obejść zasadnicze pytanie: powrót, ale do czego? Czy aby owa „ziemia obiecana” nie była wówczas jedynie fantasmagorią? Czy sam pomysł numeru nie był jedynie próbą grzecznościowej rekompensaty straconych lat PRL-u? Przed takimi wątpliwościami nolens volens musieli stanać badacze, zanim powrót ten ogłosili. Wśród nich Anna Nasiłowska, która nieco prowokacyjnie pisała wówczas:

Trudno zostać krytykiem o orientacji psychoanalitycznej nie mając możliwości odwoływania się do tej orientacji w psychiatrii, a w takiej sytuacji jest polski literaturoznawca, który nie należy do żadnej ze „szkół” (choć kilka udało mu się skończyć), a seans psychoanalityczny widział tylko na filmie (amerykańskim, Woody Allena). Ale cóż! Jeśli jest ciekaw głębin duszy, to rusza przed siebie, przywołując na pomoc kogo może: psychologa, lingwistę, mędrca, którego zna z kiepskich tłumaczeń lub nawet z „drugiej ręki”. Zobaczymy, co z tego wyniknie. ${ }^{3}$

Ale zarówno Nasiłowska, czemu daje wyraz w przywoływanym tekście, jak i inni badacze wiedzieli już wtedy, że mimo zawiłości historycznych i zmarnowanego dla psychoanalizy półwiecza, jest do czego wracać i że psychoanaliza, jak mogło się wówczas wydawać, już na długo przed wojną nie była w polskiej nauce i kulturze zjawiskiem obcym, marginalnym, niewiele znaczącym.

Wówczas, pod koniec lat 9o., można było zdawać sobie z tego sprawę na podstawie nielicznych, acz jednak powstających prac badaczy reprezentujących różne dyscypliny, a tym samym - dalekich od panoramicznego obrazu zagadnienia. Już w latach 70. Stanisław Burkot i Jerzy Speina prześledzili - niezależnie od siebie - wpływ psychoanalizy na międzywojenne

2 Zob. "Teksty Drugie" $1998 \mathrm{nr} 1 / 2$.

3 A. Nasiłowska Psychoanalityk na bezdrożach, "Teksty Drugie" 1998 nr 1/2, s. 4. Po latach badaczka wspomina, że powrót ten został ogłoszony niezbyt skutecznie. Zob. A. Nasiłowska Tematy modne, w: Tematy modne. Studia interdyscyplinarne, red. Ł. Grajewski, J. Osiński, A. Szwagrzyk, P. Tański, Zakład Antropologii Literatury i Edukacji Polonistycznej UMK, Toruń 2015, s. 278. 
badania literackie $e^{4}$. Początek lat 9o. przyniósł z kolei pracę Zbigniewa Pawlaka i Krzysztofa Sokolika - ważny, choć dziś już bardzo rozwinięty rekonesans ${ }^{5}$. W końcu zaś, w 1997 roku Paweł Dybel ogłosił szkic zatytułowany Urwane ścieżki, czyliz dziejów psychoanalizy w Polsce zaborów i międzywojnia, przedrukowany później w książce pt. Urwane ścieżki. Przybyszewski - Freud - Lacan 6 . Po prawie dwu dekadach od opublikowania tej rozprawy wciąż trwają prace nad monograficznym ujęciem dziejów psychoanalizy w Polsce, którego pierwsza część ukazała się w niedawno i stanowi przedmiot mojego omówienia - książka Pawła Dybla Psychoanaliza - ziemia obiecana? Dzieje psychoanalizy w Polsce 19oo-1989, część I: Okres burzy i naporu. Poczattki psychoanalizy na ziemiach polskich okresu rozbiorów 1900-1918, inicjująca nową serię wydawniczą Universitas „Dzieje psychoanalizy w Polsce”.

Można zatem postawić pytanie: już czy nareszcie? Najlepszym w mojej ocenie sformułowaniem będzie jednak - we właściwym czasie. To mniej więcej dwadzieścia lat, które upłynęły od momentu ukazania się pierwszych systematycznych prac poświęconych dziejom psychoanalizy w Polsce, nie było bowiem przez polskich historyków psychoanalizy (jeśli można badaczy tych tak określić) czasem zmarnowanym. Wiele tekstów, które powstały w tym okresie - od rozpraw publikowanych w przeróżnych periodykach po obszerne monografie, a których autorów wymienić tutaj niepodobna, niewątpliwie realnie wpłynęło na naszą świadomość o dokonaniach „polskich” psychoanalityków i psychoanalizy sympatyków? ${ }^{7}$ I bez względu na to, jak ma

4 Zob. S. Burkot Od psychoanalizy klinicznej do literackiej, "Rocznik Naukowo-Dydaktyczny WSP w Krakowie" 1978 z. 68; J. Speina Psychoanaliza w badaniach literackich w Polsce okresu międzywojennego, w: Z dziejów nauki polskiej. Księga pamiq̨tkowa Towarzystwa Naukowego w Toruniu, red. A. Hutnikiewicz, L. Janiszewski, PWN, Warszawa 1975. Z nowszych prac na ten temat warto odnotować: L. Magnone Emisariusze Freuda. Transfer psychoanalizy do polskich sfer inteligenckich przed drugą wojną światowq̨, Universitas, Kraków 2016.

5 Zob. Z. Pawlak, K. Sokolik Historia psychoanalizy w Polsce, "Nowiny Psychologiczne” $1992 \mathrm{nr} 4$.

6 Zob. P. Dybel Urwane ścieżki, czyliz dziejów psychoanalizy w Polsce zaborów i międzywojnia „,Res Publica Nova" 1997 nr 5; także w: tegoż Urwane ścieżki. Przybyszewski - Freud - Lacan, Universitas, Kraków 2000.

7 Pisząc o "polskich" psychoanalitykach, biorę to określenie w cudzysłów, gdyż - czego przekonywająco dowodzi Dybel - mówienie o przynależności narodowej ludności zamieszkującej ziemie polskie na przełomie XIX i XX wieku, kiedy nie istniała polska państwowość, jest nadużyciem. „Ostatecznie - przekonuje badacz - za psychoanalityka austriackiego, brytyjskiego czy polskiego należałoby uznawać przede wszystkim tych, którzy działali na rzec rozwoju psychoanalizy w tych krajach, pisali teksty w ich narodowym języku, w nim też prowadzili głównie terapię pacjentów". P. Dybel Psychoanaliza - ziemia obiecana? Dzieje psychoanalizy w Polsce 
się psychoanaliza w praktyce terapeutycznej czy jako słownik teoretyczny współczesnej humanistyki, osiągnięcia te są już przypomniane i znane, a niektóre prace nawet zostały przedrukowane, jak chociażby rozprawa Gustawa Bychowskiego o Juliuszu Słowackim ${ }^{\text {. }}$

Autor omawianego dzieła zresztą ma tego pełną świadomość:

sytuacja ta - pisze - wyznacza całkiem innego rodzaju tło dla obecnej książki, niż miało to miejsce w trakcie pisania Urwanych ścieżek. Jest to bez wątpienia tło znaczniej bardziej „przyjazne”, autor tej pracy musi jednak zmierzyć się z nowymi oczekiwaniami ze strony młodszej generacji badaczy i czytelników, posiadających już znacznie głębszą wiedzę na temat psychoanalitycznych koncepcji, ich wpływem na współczesną filozofię i humanistykę, niż to było ponad dwadzieścia lat temu. ${ }^{9}$

Dybel w swojej książce nie pozostaje jednak wobec tych ustaleń bezkrytyczny, rzuca na nie nowe świtało i lokuje je w bardzo rzetelnie zrekonstruowanych kontekstach historyczno-społecznych. Dzięki temu, choć oczywiście trudno oceniać zaplanowaną z góry całość na podstawie zaledwie jednego jej fragmentu, pierwsza część Dziejów psychoanalizy w Polsce na taką ocenę niewątpliwie pozwala i zasługuje.

Pierwszy rozdział publikacji (Tło historyczne narodzin psychoanalizy w Polsce) ma charakter rozpoznawczy i - jak można sądzić - wprowadzający w problematykę całego zaplanowanego cyklu. I tak, oprócz krótkiego zarysowania historii nurtu na przestrzeni lat 1900-2015 i przywołania bieżącego stanu badań nad zagadnieniem, zawiera on wstęp metodologiczny. Jest to tym samym - choć to trywialna obserwacja, muszę ją w tym miejscu zamieścić - jeden z najważniejszych fragmentów pracy. Sam autor nie ukrywa, że:

Prowadząc te badania, jest się [...] często konfrontowanym z doświadczeniem podobnym temu, jakie stało się udziałem owych archeologów,

1900-1989, część I: Okres burzy i naporu. Początki psychoanalizy na ziemiach polskich okresu rozbiorów 1900-1918, Universitas, Kraków 2016, s. 80-81.

8 Zob. G. Bychowski Słowacki i jego dusza. Studium psychoanalityczne, wstęp i oprac. D. Danek, Universitas, Kraków 2002. Zob. także: A. Nasiłowska Psychoanalityki dusza Słowackiego, w: tejże Persona liryczna, Wydawnictwo IBL PAN, Warszawa 2000.

9 P. Dybel Psychoanaliza-ziemia obiecana..., s. 36-37. 
którzy odkryli w podziemnych kanałach Rzymu piękne sale ze wspaniale zachowanymi malowidłami ściennymi. Te jednak, w momencie, kiedy dostało się do nich powietrze, zaczęły błyskawicznie tracić kolor i zanikać. Inna sprawa, że historia nie zna pojęcia idealnie zakonserwowanego obrazu jakiejś minionej epoki, odpornego na działanie czasu i zapomnienia. ${ }^{10}$

Sięgając do czasów, wydawać by się mogło, nie tak znów odległych, Dybel musiał dotrzeć do źródeł często zapomnianych, niekiedy geograficznie odległych, w końcu - zaginionych albo zniszczonych. Nie było to bez wątpienia zadanie łatwe, a z pewnością żmudne i czasochłonne. Wystarczy zaznaczyć, że poszukiwania te nie ograniczały się tylko do kontynentu europejskiego! Jednak odnalezione, wyselekcjonowane i wykorzystane przez niego materiały zdumiewają, po pierwsze, swoją ilością, po drugie - wartością przy odtwarzaniu rozwoju „polskiej” myśli psychoanalitycznej, kiedy ta dopiero co się kształtowała.

Pierwszy rozdział książki to także zarysowanie tła społecznego narodzin psychoanalizy na ziemiach polskich. To jeden z zasadniczych walorów omawianej publikacji. Perspektywa autora nie ogranicza się bowiem wyłącznie do „wąskiej” faktografii dotyczącej rozwoju psychoanalizy na początku minionego stulecia. Praca ta to także, a może - przede wszystkim, studium społeczeństwa, któremu przyszło zmierzyć się z dokonaniami Freuda. Nie należy bowiem zapominać, że - jak swego czasu pisał Erich Fromm - przełom XIX iXX wieku w kontekście ówczesnego życia społeczno-politycznego był okresem szczególnie podatnym na te odkrycia:

Nietrudno dostrzec powody nagłego rozkwitu psychoanalizy. W tym stuleciu, w „wieku lęku”, jak w żadnym innym potęgowało się poczucie samotności i wyizolowania. Upadek religii, jałowość powierzchownie postrzegalnej polityki, pojawienie się całkowicie wyobcowanego „człowieka zorganizowanego" - pozbawiły miejską klasę średnią zarówno układu odniesień, jak i poczucia bezpieczeństwa w bezsensownym świecie. Wprawdzie nieliczni znajdowali nowe układy odniesienia w surrealizmie, w skrajnościach politycznych albo w buddyzmie zen, jednak rozczarowani liberałowie szukali przeważnie takiej filozofii, której wyznawanie nie wymagałoby zasadniczej zmiany zapatrywań, a tym samym nie

Tamże, s. 33-34. 
spowodowałoby stania się „innymi” niż przyjaciele i koledzy. Psychoanaliza zaspokajała tę potrzebę."

Dybel nie pomija tu szczegółowych analiz, w których wiąże fakty w polskim dyskursie dotychczas marginalizowane. Przede wszystkim, co sugeruje już formuła zawarta w tytule pracy - „ziemia obiecana”, autor książki łączy rozwój psychoanalizy z procesami asymilacji Żydów na przełomie XIX i XX stulecia. Zadaje tym samym kolejne pytania: o to, czy psychoanaliza w ogóle jest nauką, dalej zaś - czy jest nauką żydowską. W konsekwencji, wpisując wcześniejsze obserwacje w kontekst polski, wyjaśnia znaczenie kwestii narodowościowych dla rozwoju psychoanalizy na ziemiach polskich:

W fakcie, że w początkowym okresie założone przez Freuda Wiedeńskie Towarzystwo Psychoanalityczne tworzyli sami Żydzi, należy przede wszystkim upatrywać efekt specyficznych okoliczności społecznych i kulturowych, jakie w monarchii austro-węgierskiej panowały na przełomie XIX i XX wieku, a nie tworzyć wokół niego rodzaju narodowej mitologii. Późniejsze dzieje psychoanalizy, która niczym „zaraza” rozprzestrzeniła się na inne kraje i kontynenty, będąc uprawiana przez osoby o różnej narodowości, wyrosłe w różnych kulturach, poświadczyły wymownie uniwersalistyczne roszczenie tkwiące u podstaw teorii Freuda. ${ }^{12}$

Stąd też drugi rozdział omawianej publikacji (Okres burzy i naporu 19o9-1919), niewątpliwie stanowiący centrum prowadzonych przez Dybla rozważań, dotyczy już stricte rozwoju „polskiej” myśli psychoanalitycznej. Pewne wątpliwości, nieumniejszające w żadnej mierze wartości tej rozprawy, budzi w tym miejscu przyjęta przez autora cezura. We wzmiankowanych już Urwanych ścieżkach... Dybel pisze:

Wspomnienia Nunberga pozwoliły nam rozpocząć opowieść o polskiej psychoanalizie w czasie mityczno-kulturowym. Jak ją rozpocząć w czasie historycznym? Tu historia nie pozostawia już żadnych pytań: zaczyna się

11 E. Fromm Kryzys psychoanalizy. Szkice o Freudzie, Marksie i psychologii społecznej, przeł. W. Brydak, Dom Wydawniczy Rebis, Poznań 2012, s. 9. 
ona wraz z założeniem przez Ludwika Jekelsa pod koniec XIX stulecia (1897) na Górnym Śląsku, w Bystrej w Bielsku, pierwszego sanatorium („Wasserheilanstalt”), w którym - m.in. wraz z Nunbergiem - stosował psychoanalizę jako formę terapii. ${ }^{13}$

Tymczasem omawiana tu publikacja już w tytule wskazuje na rok 1900 jako początek rozwoju psychoanalizy na ziemiach polskich. Dybel nie odnosi się do tej kwestii, rewiduje jedynie swoje wcześniejsze ustalenia:

Niestety, nie rozporządzamy dziś odpowiednią dokumentacją i innymi świadectwami, na podstawie których moglibyśmy wiarygodnie stwierdzić, w jakim zakresie i od kiedy Jekels i Nunberg zaczęli w Bystrej stosować psychoanalizę. Z pewnością jednak nie było w 1897 roku, zaś później mogło się odnosić co najwyżej wąskiej grupy pacjentów. ${ }^{14}$

Jasne jest przy tym, że trudno o wyznaczenie dokładnej daty, każdy zaś wybór byłby w tym wypadku obciążony arbitralnością. Jednak przyjęcie roku 1900 jako początku rozwoju psychoanalizy na ziemiach polskich zdaje mi się ujęciem niewystarczająco ścisłym. Tym bardziej, że początek okresu „burzy i naporu" w „polskiej” myśli psychoanalitycznej Dybel precyzyjnie lokuje dopiero w roku 1909, czyli od I Zjazdu Neurologów, Psychiatrów i Psychologów Polskich, który odbył się w Warszawie. To jednak, rzecz jasna, kwestia otwarta i dyskusyjna.

Co warte podkreślenia, Dybel osobny podrozdział poświęca pierwszym przekładom prac Freuda na język polski. Jest to niezwykle ważny fragment tej pracy, biorąc pod uwagę, jak - szczególnie dla badaczy nieznających języka niemieckiego - istotne i konieczne jest korzystanie z rzetelnych przekładów. A tymi, co do czego nie ma wątpliwości, były prace ucznia autora Die Traumdeutung i praktykującego psychoanalityka, Ludwika Jekelsa: O psychoanali$z i e^{15}$ oraz Psychopatologia życia codziennego (wraz z Heleną Ivánką) ${ }^{16}$. Tłumaczenia powstałe w ostatnich latach, co w wielu swoich pracach szczególnie

13 P. Dybel Urwane ścieżki.., s. 27.

P. Dybel Psychoanaliza-ziemia obiecana..., s. 115.

Zob. Z. Freud O psychoanalizie, przeł. L. Jekels, Księg. H. Altenberg, Lwów 1911.

16 Zob. Z. Freud Psychopatologia życia codziennego. O zapominaniu, pomyłkach, zabobonie i błędach, przeł. L. Jekels, H. Ivanka, H. Altenberger, G. Seyfarth, E. Wende i sp., Lwów 1913. 
podkreśla Danuta Danek ${ }^{\mathbf{1 7}}$, są często wręcz absurdalne, niezrozumiałe i wypaczają istotę obserwacji Freuda. Stąd wyrażam nadzieję, że po ukończeniu Dziejów psychoanalizy w Polsce, a w rezultacie - kiedy już będziemy dysponowali pełnym obrazem dokonań „polskich” psychoanalityków, przyjdzie czas na wznowienie ich prac $^{\mathbf{1 8}}$, a tym samym - lepsze zrozumienie Freudowskich teorii, zanim - co dziś nietrudno zaobserwować - zostaną one okrzyknięte mianem anachronicznych czy maniakalnych.

Dysponowanie przekładami dzieł Freuda już w drugiej dekadzie XX wieku miało zresztą ogromny wpływ na recepcję psychoanalizy na ziemiach polskich w kręgach filozoficznych i artystycznych. Temu odbiorowi Dybel poświęca kolejny, trzeci rozdział swojej książki (Pierwsze fascynacje. Recepcja psychoanalizy w polskiejfilozofii), datując go od roku 1912, a więc - co warte zauważenia - niebawem po ukazaniu się Jekelsowskiego przekładu O psychoanalizie.

Psychoanaliza często pojawiała się na łamach lwowskiego „Ruchu Filozoficznego" wydawanego przez Kazimierza Twardowskiego, jednego z najważniejszych „polskich” filozofów tamtego czasu. Z kolei wśród pisarzy pierwszy poświęcił jej uwagę Karol Irzykowski w kilku esejach ogłaszanych na łamach krakowskiej „Nowej Reformy” czy warszawskich „Prawdy” i „Świata”. Dybel nie poprzestaje wyłącznie na przywołaniu czy zreferowaniu wymienionych tekstów. Komentuje je, wykazuje ich ułomności, ale i - podkreśla ich niebagatelne znaczenie dla rozwoju „polskiej” psychoanalizy i zainteresowania nią w kręgach artystycznych.

Autor przywołuje w tym miejscu także artykuł Ottona Hewelkego z 1903 roku zatytułowany Kornelia-Metella w „Irydionie” Krasińskiego, zauważając, że:

We wspomnianej rozprawie zarysował [Hewelke] obraz tej bohaterki, której zachowanie nosi jego zdaniem wszelkie znamiona zachowań histeryczek. Co ciekawe, w artykule tym Hewelke nigdzie nie powołuje się na Freuda. ${ }^{19}$

17 Zob. np. D. Danek Żałoba i melancholia albo poniżej dna, "Twórczość” 1993 nr 3; tejże Freud w polskich wersjach edukacyjnych, "Twórczość” 2004 nr 4.

18 W chwili, gdy napisałem niniejszy tekst, stał się już dostępny niezwykle interesujący wybór „polskich” prac poświęconych psychoanalizie z lat 1900-1918, w którym możemy odnaleźć m.in. teksty Jekelsa, Hewelkego czy Irzykowskiego. Zob. Od Jekelsa do Witkacego. Psychoanaliza na ziemiach polskich pod zaborami 1900-1918. Wybór tekstów, red. B. Dobroczyński, P. Dybel, Universitas, Kraków 2016.

P. Dybel Psychoanaliza - ziemia obiecana..., s. 201. 
Przywołuje, ale bodaj bardziej z historiograficznej dokładności niż ze względu na jego wartość czy prekursorstwo.Zdaje mi się, że Dybel także nieco na siłę stara się wyeksponować podobieństwa między ujęciem Hewelkego i Freudowską psychoanalizą. Podobnie zresztą, choć w tym wypadku pisano już na ten temat wcześniej, autor omawianej publikacji wskazuje pokrewieństwo teorii marzeń sennych i onirycznej kreacji Pałuby Irzykowskiego. Tu jednak Dybel zachowuje daleko idącą ostrożność, wykazując, po pierwsze, jak różne są to modele, i po drugie, że Irzykowski, pisząc Pałubę, wcale nie znał prac Freuda.

Słowem dopowiedzenia muszę w tym miejscu zwrócić uwagę na ważne rozróżnienie, które, jak sądzę, bliskie jest także autorowi omawianego dzieła: czym innym jest uprawianie badań literackich w duchu psychoanalitycznym, a czym innym - doszukiwanie się wpływów świadomości postpsychoanalitycznej na twórczość literacką. W pierwszym wypadku mamy bowiem do czynienia z postępowaniem badawczym, choć arbitralnym, to jednak jak najbardziej uprawnionym i odpowiednim do analizy utworów pochodzących z każdej epoki, w drugim natomiast często musimy pozostawać w sferze domysłów i przypuszczeń, szczególnie jeśli mowa o początkach rozwoju myśli psychoanalitycznej. Choć jest to obserwacja nader oczywista, w jej kontekście praca Dybla nabiera szczególnego znaczenia. Pozwala nie tylko na zrozumienie trudnych początków myśli psychoanalitycznej na ziemiach polskich, ale także daje możliwość prześledzenia, jak rozwijała się świadomość psychoanalityczna w pierwszych dekadach minionego wieku i tym samym - jest niezastąpionym punktem wyjścia dla literaturoznawców zajmujących się tym okresem.

Ostatni rozdział Dziejów psychoanalizy... (Psychoanaliza i prawda seksualności) Dybel poświęca z kolei konfliktom natury religijnej i obyczajowej, które wyniknęły ze zderzenia rozpowszechnianych na ziemiach polskich poglądów Freuda z nauczaniem Kościoła. Przyczyną owego konfliktu było, rzecz jasna, po dziś dzień opatrznie rozumiane podkreślanie przez psychoanalityków znaczenia ludzkiej seksualności dla rozwoju psychicznego, a także całkowicie inny „wizerunek własny” człowieka niż ten funkcjonujący w wieku XIX i na początku XX.

„Tak ogromną władzę posiadał wtedy Kościół katolicki w Polsce!” [- relacjonował w swoich wspomnieniach Nunberg]. Była to oczywiście władza nad „duszami”, ale przez nie też i nad ciałem. Przejawiała się ona w występowaniu Kościoła w roli ostatecznej moralnej instancji przy ocenie 
różnego rodzaju zachowań w sferze publicznej i prywatnej (do tej ostatniej Kościół miał dostęp dzięki instytucji spowiedzi), w szczególności zaś tych, które dotyczyły sfery seksualnej. Psychoanaliza musiała się przy tym wydawać jego przedstawicielom szczególnie podejrzana ze względu na jej „konkurencyjne" roszczenie dokonania głębokiej zmiany w samowiedzy pacjenta. ${ }^{20}$

Opisywane przez Dybla koleje losu „polskich” pionierów myśli psychoanalitycznej nie mają, niestety, dobrego zakończenia. Wybuch I wojny światowej wywołał stagnację w rozwoju ich badań i upowszechnianiu zapoczątkowanej przez Freuda myśli. Dopiero po roku 1918, już w niepodległej Polsce, mogły być one kontynuowane. I - oczywiście były, dlatego też wymagają szczegółowego opracowania, na wzór tego tu omawianego.

Czytelnik nieprofesjonalny czy badacz otrzymał już bowiem wieloaspektowy obraz pierwszych lat rozwoju „polskiej” psychoanalizy, przyswajania dokonań Freuda i jego uczniów oraz pierwszych inspiracji artystycznych płynących z tej teorii. Obraz pełny, kompetentnie skreślony i zapowiadający przez to bardzo interesującą kontynuację. 


\section{Abstract}

\section{Jakub Osiński}

NICOLAUS COPERNICUS UNIVERSITY (TORUŃ)

'A New Idea Always Seems Difficult...'

Review: Paweł Dybel, Psychoanaliza - ziemia obiecana? Dzieje psychoanalizy w Polsce 1900-1989 [Psychoanalysis - the Promised Land? A History of Psychoanalysis in Poland 1900-1989], part I: Okres burzy i naporu: Początki psychoanalizy na ziemiach polskich okresu rozbiorów 1900-1918 [Sturm und Drang: The Beginnings of Psychoanalysis on Polish Lands During the Partitions 1900-1918], TAiWPN Universitas, Cracow 2016, 264 pp.

\section{Keywords}

psychoanalysis, history of psychoanalysis, Sigmund Freud, history of Poland 1900-1918 